\title{
DIFFERENTIAL INTERFEROMETRY AS A TOOL OF AN EARLY WARNING SYSTEM IN REDUCING THE VOLCANO RISK: THE CASE OF NISYROS VOLCANO
}

\author{
Is. Parcharidis, E. Lagios and V. Sakkas
}

National Kapodistrian University of Athens, Laboratory of Geophysics, Department of Geophysics \& Geothermics, Panepistimiopolis - Ilissia, 15784 Athens, Greece, parchar@geol.uoa.gr, lagios@geol.uoa.gr, sakkas@geol.uoa.gr.

\begin{abstract}
In this study an attempt to evaluate the possibility to use the interferometric (InSAR) technique as an operational tool in an early warning system concerning the volcanic hazard, is presented. The InSAR techniques was appied in Nisyros volcanic island which during 1996-1998 show an intensive seismic unrest. Two interferometric images were created covering the period before the seismic activity (1995-1996). In the two interferometric images fringe patterns of deformation were recognised related to the ground deformation occured before the seismic unrest period.

The operational capabilities of the technique is mainly restricted by the low repetitevily of the image aquisitions and the parameters to take in consideration like perpendicular baseline, atmospheric conditions etc.
\end{abstract}

\section{INTRODUCTION}

It is known that certain natural hazards, among them volcanic activities, produce deformation before the activity, during, after and between the events.

In this study, in the frame of Geowarn E.U project (IST 12310), an attempt was carry out in order to demonstrate the feasibility of using space techniques like differential interferometry (DInSAR) as an operational tool integrated in a early warning system (EWS).

Satellite remote sensing is providing to be an effective tool for hazard and risk assessment, damage mitigation etc. There are two distinct circumstances in which volcanologists monitor activity at volcanoes: (1) unrest at a volcano that has been dormant, but which may be preparing to erupt and (2) activity at a volcano during an eruption, particularly a long-term eruption with spurts of accelerated activity or pauses (as at Kilauea, or Etna, or the slow dome-building eruptions of Montserrat or Unzen). In the first instance, the volcano will erupt only if there is renewed influx of magma from deep within the earth. Magma movement triggers earthquakes and tremor, hence the widespread use of seismic networks as the monitoring method of first resort. Satellite monitoring can come into play only when the magma is near enough to the surface to produce surface deformation, or enhanced heat flow or gas emissions (Francis et al. 1996).

DInSAR is the technique that allow to monitoring surface deformation produced i.e. by volume changes in the crustal magma chamber or by a seismic event (Coulson 1993, Massonnet and Rabaute 1993, Lu et al 1997, Kobayasshi et al, 1999, Parcharidis and Lagios 2000, Clifton et al. 2002, Sachapazi et al. 2002).

The test site for the application was Nisyros island due to its unique situation which includes complex volcanic and related hazards (Fytikas et al. 1984, Francalanci et al.1995). In 1996 (during the summer) and 1997 seismic activity started with earthquakes of magnitudes up to 5.5 and with hypocenters down to $10 \mathrm{~km}$ depth, damaging 30 houses in Mandraki. The detection of the potential deformation on the island before the seismic unrest is the main task. 


\section{NISYROS VOLCANO}

The eastern sector of the Aegean volcanic arc, including the islands of Kos, Yali and Nisyros seems to be geodynamically very active, since it comprises large volumes of young volcanic products. Although the Dodekanese Islands, the Bodrum Peninsula and Kos have been affected by magmatic and volcanic activity since approximately 12 million years (Fytikas et al. 1976 \& 1984, Pe-Piper \& Piper 2002), high geodynamic activity in the Kos-Yali-Nisyros volcanic field started in the Pliocene (approx. 2.6-2.8 my) and ended with a large with phreato-magmatic eruption 165 thousand years before (Smith et al. 1996). Large remnants of this eruptive event are present in the Kos island, on Kalymnos and in the islets of Pergussa and Pachia.

The island of Nisyros is a Quaternary volcano located at the easternmost end of the Aegean volcanic arc, in the Dodecanese Archipelago, south of Kos. The island is almost circular, with an average diameter of $8 \mathrm{~km}$, covering an area of about $42 \mathrm{~km}^{2}$. It lies above a basement of Mesozoic limestone and a thinned crust, with the Moho located at a depth of about $27 \mathrm{~km}$ (Makris \& Stobbe 1984). The composite volcanic edifice of Nisyros comprises a succession of calc-alkaline lavas and pyroclastic rocks, with a summit caldera of a $4 \mathrm{~km}$ average diameter. According to Di Paola (1974), Keller et al. (1990), Papanikolaou et al. (1991), Limburg \& Varekamp (1991), Vougioukalakis (1993), Hardiman (1999), the caldera is due to two major Plinian eruptive phases followed by a collapse, approximately 30,000 to 15,000 years ago.

Four major directions of fault systems can be distinguished within the volcanic edifices of the Kos-Yali-Nisyros volcanic field. The results are in accordance with previous structural and geological investigations (Papanikolaou et al. 1991, Vougioukalakis 1993, Papanikolaou \& Nomikou 2001).

F1) N3OE faults with local changes to NE directions

F2) N30W faults with changes between $\mathrm{N} 20^{\circ}$ and $\mathrm{N} 40^{\circ}$

F3) E-W faults

F4) N-S faults

High geodynamic activity is a common phenomenon on the island of Nisyros and in the entire Kos Yali - Nisyros volcanic field. Earthquakes have been described since historical times and recorded in detail in 1830, 1871-73, 1887, 1953, 1961 and 1968-71 (Makropoulos et al. 1989). Their origin may be a result of regional tectonic processes, magma ascent, degassing phenomena of deep crustal magma and steam explosions within the hydrothermal system as "hydrothermal noise".

During the most recent seismic crisis between 1995 and 1997 (Papadopoulos et al. 1998) several shallow tectonic earthquakes down to $10 \mathrm{~km}$ depth with magnitudes up to $M=5.5$ occurred along this fault system between Tilos and Kos. A reactivation of the F2 fault system (with direction from SSE to NNW and most probably extending into the sea, reaching the Yali coast to the north) passing through Mandraki was clearly noticed (Ioannides 1998). This particular fault system caused many damages in the houses of the small town, as it was actually passing through the narrow streets, cutting off house floors, walls and yards accompanied by increased tectonic and fumarolic activity along the western edge of the hydrothermal crater field. Parcharidis \& Lagios (2001), Sachapazi et al. (2002) and Sykioti et al. (2003) applied differential interferometric technique to measure the ground deformation during the seismic unrest period.

\section{METHODOLOGY, DATA USED \& PROCESSING}

The satellite imaging radar (SAR) instrument works by beaming coherent microwave radiation to the Earth's surface and recording the backscattered signal reflection from objects on the ground retaining both amplitude and phase information in the radar echo during data acquisition and subsequent processing. This radiation can be described by three properties (Fig 1):

Wavelength - the distance between peaks on the wave.

Amplitude - the displacement of the wave at the peak.

Phase - describes the shift of the wave from some other wave. Phase is usually measured in angular units, like degrees or radians. 


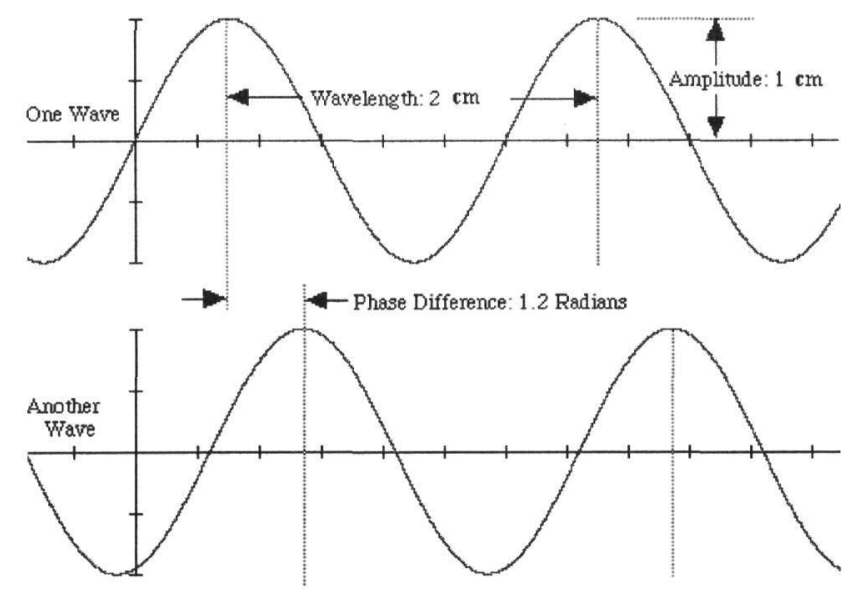

Figure 1. Radiation properties and phase shift (source:ESA, www.esrin.esa.it)

Synthetic Aperture Radar (SAR) interferometry exploits this coherence using the phase measurements to infer differential range and range change in two or more complex-valued SAR images of the same surface, thereby deriving more information about an object than is obtainable with one single image.

Using two radar scenes, forming an interferometric pair, of a common area acquired on two different passes in time an interferogram could be created. This interferogram is created, through a complex and computer-intensive process, from the phase (or wave) information of the radar data and consists of fringes, which cycle from black, through shades of grey, to white or as a sequence of colors like blue-green red. These cycles represent phase differences between the corresponding reflected signals, for each common ground point, acquired at the two different satellite passes, these fringes result from the physical separation, and hence the slightly different imaging angles of the radar instruments. Within each fringe, a given shade of grey or color represents a particular phase difference, and all points of a particular shade or color will exhibit the same phase difference. Each displacement fringe in a differential interferogram is a result of the satellite-to-ground path length difference, and is measured down to units of wavelengths of the radar sensor, which, for the ERS satellites, is $5.6 \mathrm{~cm}$. Again, from the satellite orbit acquisition geometry and the physical parameters of the radar sensor, each distinct fringe cycle in the differential interferogram actually represents $2.8 \mathrm{~cm}$ (half a wavelength) of movement in the look-direction, or line-of-sight of the sensor on the satellite platform.

Table 1. The selected interferometric pairs

\begin{tabular}{llllll}
\hline InSAR pair & Master orbit & Date & Slave Orbit & Date & Bp $(\mathrm{m})$ \\
\hline 1 & 20135 & May 22, 1995 & 23642 & Jan 22, 1996 & 85 \\
\hline 2 & 21638 & Sept 4, 1995 & 6975 & Aug. 20, 1996 & 58 \\
\hline 3 & 641 & Jun 4, 1995 & 25324 & May 18, 1996 & 7 \\
\hline
\end{tabular}

There are a number of parameters that should be take in consideration in order to obtain the best interferometric results such the quality of the data, the perpendicular baseline and the temporal separation between the two acquisitions, the coherence between the two scenes (depended on the ground characteristics) and the quality of the digital elevation model needed to subtract the topography of the area.

In order to select suitable interferometric pairs covering the period before the summer of 1996 the EOLI data base of European Space Agency was scanning. Table 1 contains the interferometric pairs selected for this study as well as their characteristics. 
SAR processing, production of Single Look Complex Image (SLCI) from raw data and differential interferometric analysis was based on Atlantis s/w using the "two passes plus DEM" method. The main steps of the processing were:

Coregistration between the two SLCl images, the main purpose of the coregister processing step is to resample the slave SAR image to be coregistered with the master SAR image.

Coregistration analysis, the main purpose is to validate the input master/slave interferometric pair for spatial and spectral overlap.

Coregister external DEM to master SAR image, pixel-by-pixel coregistration of the external DEM (pixel=2m) with the master image. The external DEM was converted to a true (distorted) slant range/azimuth projected DEM and then to asimulated SAR image.

Generate the interferogram and filtering for baseline deccoralation in range and for azimuth spectral overlap in azimuth along the way.

Flat earth phase and the the topographic phase was also subtracted using the baseline correction.

Calculation of the phase coherence map and evaluation, phase unwrapping throught the generation of an unwrapping control mask. According to the method circular disks centered on phase residues and pixels of low coherence were applied.

From the above three interferometric pairs (table 1) only for the first two were obtained results, the processing of the third pair was unsuccessful due to the low quality of the data (poor spectral azimuth overlapping between the two scenes)

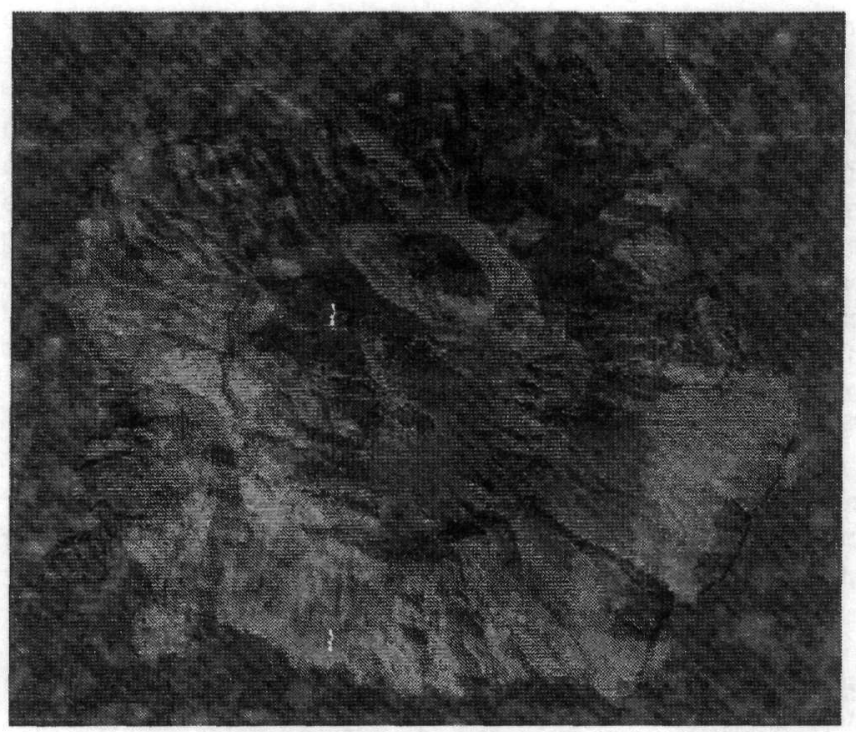

Fig. 2 Differential interferometri image of period 22-5-95/22-1-96

\section{RESULTS-CONCLUSIONS}

In both cases the obtained coherence was good to fairly good for most of the island except for the northwestern part of the island. The produced interferogram from the first pair covers the period 22-5-95 to 22-1-96 clearly before the seismic unrest period. In the image one interferometric fringe , covering most of the island, equivalent to $28 \mathrm{~mm}$ of ground deformation along the line of sight of the sensor was recognized and evaluated. A second fringe located on the SW extremity of the island was also recognized. The produced interferogram from the second pair covers the period 4-9-95 to 20-8-96 coinciding with the beginning of the seismic unrest period. In the image two inerferometric fringes were recognized. One fringe is spatially distributed over the whole island showing almost horseshoe shape opened in the NW part of the island, the second fringe is fully displayed only in 
the SW part of the island and partially along the sothern coast zone. Where the second fringe is located the corresponding deformation is $5.6 \mathrm{~cm}(2 \times 28 \mathrm{~mm})$ along the line of sight of the sensor.

Limited spatial and temporal resolution of available satellite data means that, for most proximal hazards, it is used mainly as supplemental information for current eruptions, and post-disaster assessment in mitigation and prevention of future disasters.

The implemantation of operational disaster management solutions that use the capabilities of space systems can be achieved through the development of solutions that integrate the use of space-based technologies, including services and other products of space systems, with other nonspace sources such as ground information.

The results clearly show the necessity for DiNSAR technique to be included systematically as an important component in a EWS although actually it is not possible to apply the technique in "real time".

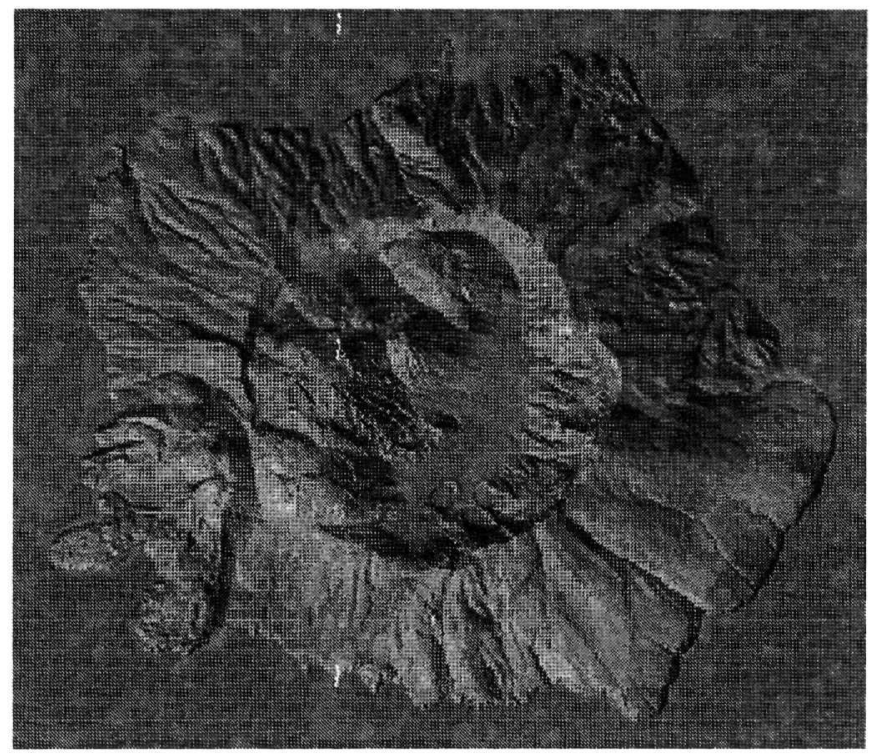

Fig. 3 Differential Interferometric image for the period 4-9-95/20-8-96

\section{ACKNOWLEDGEMENTS}

The investigation was supported by the GEOWARN E.U Project (IST 12310) and the authors would like to thanks Dr. G. Stavrakakis and Dr V. Dietrich.

\section{REFERENCES}

Clifton, A.E., Sigmundsson, F., Feigl, K.L., Guomundsson, G., Arnadottir, T., 2002. Surface effects of faulting and deformation resulting from magma accumulation at the Hengill triple junction, SW Iceland, 1994-1998. Journal of Volcanology and Geothermal Research, 115(1-2), 233-255.

Coulson, S.R.,1993. SAR interferometry with ERS-1. Earth Observation Quarterly, 40: 20-23.

Di Paola, G.M., 1974. Volcanology and petrology of Nisyros Island (Dodecanese, Greece). Bull. Volcanol., 38 , 944-987.

Francalanci, L., Varekamp, J.C., Vouglioukalakis, G., Defant, M. L, Innocenti, F., Manetti, P., 1995. Crystal retention, fractionation and crustal assimilation in a convecting magma chamber, Nisyros Volcano, Greece. Bull. Volcanol,. 56 (8), 601-620.

Francis, P.W., Wadge, G., and Mouginis-Mark, P.J., 1996. Satellite monitoring of volcanoes. In Scarpa, R. and Tilling, R.I. eds., Monitoring and Mitigation of Volcano Hazards: Springer-Verlag, New York, pp. $257-298$.

Fytikas, M., Guiliani, O., Innocenti, F., Marinelli, G., Mazzuoli, R., 1976. Geo-chronological data on recent magmatism of the Aegean Sea. Tectonophysics, 31, 29-34. 
Fytikas, M., Innocenti, F., Manetti, P., Mazuoli, R., Peccerilo A., Villari, L., 1984. Tertiary to Quaternary evolution of the volcanism in the Aegean Region', In Dixon J.E. and Robertson, A.H.F. (eds.): The Geological Evolution of the Eastern Mediterranean. Geol. Soc. London, Spec. Pub. 17, 687-699.

Hardimann, J.C., 1999. Deep sea tephra from Nisyros Island, Eastern Aegean Sea, Greece. In Firth, C.R. \& McGuire, W.J. (ed.) Volcanoes in the Quaternary. Geol. Soc. (London), Spec. Publ. 161, 69-88.

Ioannides, K., 1998. Nisyros Island: Observed damages to buildings in Mandraki. Newsletter, European Center on Prevention and Forecasting of Earthquakes, 2, 33-35.

Keller, L., Rehren, Th., Stadlbauer, E., 1990. Explosive volcanism in the Hellenic Arc; a summary and review. In: D. A. Hardy, J. Keller, V. P. Galanopoulos, N. C. Flemming, and T. H. Druitt (ed), Thera and the Aegean World III. Proc. 3rd International Congress. The Thera Foundation, London 2: 13-26.

Kobayashi, S., Fujii, N., Okubo, S., 1999. Detection of Volcano deformations and co-seismic movements using JERS-1 L-band SAR differential Interferometry: Combination with other geodetic measurements. Proceedings IGARSS'99, II, 800-803.

Lagios, E., 2000. Intense crustal deformation rates on Nisyros Island (Greece), deduced from GPS studies, may foreshadow a forthcoming volcanic event. Proc. 2nd Intern. Conf. On Earthquake Hazard and Seismic Risk Reduction (S. Balassanian et al, ed.), pp. 249-259, Kluwer Academic Publishers.

Limburg, E.M., Varekamp, J.C., 1991. Young pumice deposits on Nisyros, Greece. Bull. Volcanol. 54 (1): 68-77.

Lu Z., Fatland R., Wyss M., Li, S., Eichelberer, J., Dean, K., Freymueller, J., 1997. Deformation of New Trident volcano measured by ERS-1 SAR interferometry, Katmai National Park, Alaska. Geophysical Research Letters, 24(6), 695-698.

Makris, J., Stobbe, T., 1984. Physical properties and state of the crust and upper mantle of the Eastern Mediterranean Sea deduced from geophysical data. Marine Geology, 55, 347-363.

Makropoulos, K., Drakopoulos, J., Latoussakis, J., 1989. A revised earthquake catalogue for Greece since 1900. Publ. No 2, Geophys. J. Int., 98, 391-394.

Massonnet, D., Rabaute, T., 1993. Radar interferometry: limits and potential, IEEE Trans. Geosc. \& Remote Sensing, 31, 455-464.

Nomikou, P., Papanikolaou, D., 2000. Active geodynamics at Nisyros, the eastern edge of the Aegean Volcanic Arc: Emphasis on the submarine survey. Proc.3rd Int. Conf. Geology East. Mediterranean, Sept.1998, pp. $97-103$.

Papadopoulos, G.A., Sachpazi, M., Panopoulou, G., Stavrakakis, G., 1998. The volcanoseismic crisis of 199697 in Nisyros, SE Aegean Sea, Greece. Terra Nova, 10, 151-154.

Papanikolaou, D.J., Lekkas, E.L., Sakelariou, D.T., 1991. Geological structure and evolution of Nisyros volcano. Bull. Geol. Soc. Greece 25/1, 405-419

Papanikolaou, D., Nomikou, P., 2001. Tectonic structure and volcanic centres at the eastern edge of the Aegean Volcanic Arc around Nisyros Island. Bull. Geol. Soc. Greece, vol. XXXIV/1, 289-296, Proc. 9th Intern. Congress, Athens, September 2001.

Parcharidis, Is., Lagios, E., 2001. Deformation in Nisyros Volcano (Greece) using Differential Radar Interferometry. Bull. Geol. Soc. Greece, 34/ 4, 1587-1594.

Pe-Piper, G., Piper, D.J.W., 2002. The Igneous Rocks of Greece. The anatomy of an orogen. Gebr. Bornträger, Berlin, Stuttgart, pp 1-573.

Sachapazi M. Kontoes C, Voulgaris N., Laigle M. Vougioukalakis G., Sikioti O., Stavrakis G., Baskoutas J., Kalogeras J., Lepine JC., 2002. Seismilogical and SAR signature at Nisyros caldera, Greece. Journal of Volcanology and Geothermal Research, 116 (1-2), 19-33.

Smith P.E.,York D., Chen Y., Evensen N.M., 1996. Single crystal (super 40) Ar - (super 39) Ar dating of a late Quaternary paroxysm on Kos, Greece, concordance of terrestrial and marine ages. Geophysical Research Letters, vol. 23, no. 21, 3047-3050.

Sykioti, O., Kontoes, C., Eliasm, P., Briole, P., Sachpazi, M., Paradissis, D., Kotsis, I., 2003. Ground deformation at Nisyros Volcano (Greece) detected by ERS-2 SAR differential interferometry. Int. J. Remote Sensing, 24, 183-188.

Vougioukalakis, G., 1993. Volcanic Stratigraphy and Evolution of Nisyros Island. Bull. Geol. Soc. Greece, 28/2, 239-258. 